\title{
The impact of compensation initiatives on sales force performance: A case study of the insurance industry in the Southern region, Zimbabwe.
}

\author{
${ }^{1}$ Marumbwa John, ${ }^{2}$ Makore Albert, ${ }^{3}$ Mudondo Chenjerai David \\ ${ }^{1}$ Great Zimbabwe University, ${ }^{2}$ Great Zimbabwe University, $\quad{ }^{3}$ Great Zimbabwe University
}

\begin{abstract}
This research paper examines the impact of compensation initiatives on sales force performance using a descriptive research design to conceptualize recommendations to use in designing sales force compensation. The links between monetary and non-monetary compensation initiatives are further investigated to establish their impact on sales performance and sales force turnover. A structured questionnaire was personally administered to collect primary data from a sample of 50 respondents purposefully selected. It was concluded that both monetary based compensation incentives and non-monetary incentives do not necessarily influence sale force performance. However, monetary based compensation incentives directly influences sales force turnover whilst non-monetary incentives do not necessarily influence sales force turnover.
\end{abstract}

Key words: compensation, compensation packages, sales force performance, insurance industry

\section{Introduction}

It has been noted that in many organisations, sales force compensation costs are between $40 \%$ and $75 \%$ of the marketing budget (Flint 1991 in Abratt and Klein 1999).To this effect it is suggested that companies should attempt to set aside huge sums of money in their marketing budget in order to effectively compensate their salespeople so that productivity and motivation are improved. Recent research has proved that sales personnel are the primary link between the buying and selling firms as they have considerable influence on the buyers' perceptions of the sellers' reliability, product or service and the value (Biong and Selnes 1996 in Weitz and Bradford 1999).

Personal selling is a function of strategic importance in marketing as the salesperson can engage in dialogue with the customer and solutions can immediately be prescribed matching the firm's capabilities (Blythe 2006). The ability to communicate face to face with customer makes this communication strategy more effective in business transactions. The study sought to investigate the impact of compensation initiatives on sales force performance in the insurance industry in the Southern Region (Zimbabwe). Whilst a lot of research has been undertaken on the relationship between sales management control, territory design, sales performance and sales organization effectiveness little has been done to empirically quantify the effects of various underlying compensation initiatives on sales performance. The financial package paid to salespeople has several components which may be designed to achieve different objectives and the core of sales compensation plans consists of a salary and incentives (Johnston and Marshall 2010).

\section{Objectives of the research}

The objective of this paper is to;

- Investigate the role of monetary incentives when used as motivational tools,

- Evaluate the contribution of non-monetary compensation packages on sales performance, and

- Determine the impact of compensation packages on sales force turnover.

\section{Insurance industry in Zimbabwe}

The decade that preceded the adoption of the multi-currency financial system in 2009, saw the Zimbabwean insurance industry which was once a dominant force on the African insurance platform suffering from declining confidence among the insuring public. However, the state of affairs that currently obtains in the dollarized economy has seen this sector gradually recuperating and restoring the lost insurer confidence and trust. According to www.financialgazzette.co.zw 20 August 2012, the Zimbabwean penetration ratio is estimated to be in excess of four percent (4\%) and this has attracted global foreign insurance players and investors such as AON. In an interview with a weekly business paper, The Financial Gazzette, in 2012, Nicoz Diamond Managing Director, Grace Muradzikwa revealed that: 
"........ The growth in insurance revenues is a reflection of the relative stability prevailing in the country as well as the growing risk awareness and public confidence in the insurance sector. The demand for simple and sophisticated insurance products is on the rise as corporate clients realize that they need insurance to access favorable funding from lending institutions and the increasing demand by shareholders for value preservation and creation through implementation of effective risk management practices. It is interesting to note that growth in premium revenues has also been coming from less popular products such as fidelity guarantee, hire purchase, public liability, hail insurance and many other accident class products...."

The majority of insurance companies in Zimbabwe provide a variety of insurance products and services to both individuals and companies. The products range comprises of life insurance, pension saving schemes, funeral policies, and medical-aid and investment products. Among the leading insurance companies in Zimbabwe are Old Mutual, First Mutual, and Altfin and many reinsurance companies. To help boost the recovery of the insurance sector, the Insurance Council of Zimbabwe has embarked on massive advertising and promotional campaigns to raise awareness amongst the uninsured population and to engage the government departments through lobbying for favorable economic policies that help resuscitate the sector. Some of the foreign owned companies are in the process of complying with the Zimbabwean government indigenization legislation for the purpose of empowering locals, staff, management and other relevant stakeholders. Technology is also playing critical role as mobile -commerce has made great contributions in terms of availing new products to customers.

\section{Literature review}

Piercy and Lane (2009) brings to the fore the fact that the growing importance of sales management as a discipline should be noted as its influence on strategic decisions is pertinent. Sales management has an immense role of inputs into strategic formulation as well implementing those strategies. The types of customer, such as industrial customers are characterized by fewer large customers who at times demand special sales attention, while the insurance industry is characterized by many potential buyers. The nature of the insurance product, being an unsought good requires advertising and personal selling (Kotler and Keller, 2012). Sales force compensation is a key motivator or driver of short term goals in sales hence management need to accord this critical enabler due importance. One aspect worth mentioning is the participation of the sales force in nonselling activities which also take up a great amount of time and this is important in producing results in the selling process (Ingram, LaForge, Avilla, Schwepker and Williams, 2007:13).

\section{Compensation and sales force performance}

Several scholars view compensation as a reward individuals receive in exchange for performance. Employees can be paid for the time they work, skills and knowledge, the output they produce and competencies or a combination of these competencies. According to Johnston and Marshall (2010) three basic factors drive successful compensations initiatives and these are related to specific selling situations and activities, level of incentives in relation to basic pay and finally the mix of financial ,non-financial compensation and incentives. John and Weitz (1989) provide an excellent overview of compensation initiatives and state that plans emphasizing salary require more managers resulting in a lower span of control to monitor and assess performance of salespeople.

Johnston and Marshall (2010) notes that the relationship between performance and rewards is very complex and a firm can use a variety of rewards. Of the two types of rewards, extrinsic rewards comprising of salary, financial incentives, security, recognition and promotion are said to have powerful and immediate effect (Johnston and Marshall 2010). Intrinsic motivation which is derived from within and this result in feelings of accomplishment. Previous research studies which have been carried out note that there is no significant decrements in intrinsic motivation when tangible rewards (extrinsic) are tied to outcomes or to performance (Eisenberger and Cameron 1996 in Bartol 1999; Oliver and Anderson 1995; Cravens et al. 1993). In a recent meta-analysis a positive link between financial incentives and performance was supported in the paper which largely focused on incentives related to outcomes (Bonner et al. 2000)

\section{Determination of compensation packages}

There are several factors that are contingent to the determination of compensation packages for salespeople and several studies show that salespeople's failure to perform ultimately resides with the management (Cron et.al 1988). Brown, Evans, Mantrala and Challagalla (2005) notes that it is difficult to apply the various insights into sales people compensation (Albers 2010) as the field sales job is becoming more complex. Descriptive studies carried out indicate the various compensation packages used by different companies, but these do not explain the substantial variations across and within industries (John and Weitz 1989). 
The design, implementation, evaluation and regular adjustment of incentive plans is the responsibility of sales management who have to decide on the three basic compensation plans for its sales force. The core of sales compensation plans consists of a salary and incentive payments. In missionary selling tasks, the most used plan, a salary which is a fixed sum of money paid at regular intervals (Marshall and Johnston 2010). John and Weitz (1989) agree that the role of the salary should be related inversely to the relative impact of selling effort on sales (the slope of sales response function). The amount of salary paid to a given salesperson is usually a function of that salesperson's experience, competence, and time on the job, as well as the sales manager's judgments about the quality of the individual's performance (Marshall and Johnston 2010).

A straight commission plan is useful for companies that are focussed on improving sales volume or profitability and since a direct link exists between sales volume and the amount of commission received, commission payments are useful for increasing reps' selling efforts in the short term. A bonus is a payment made at management's discretion for achieving or surpassing some set level of performance (Marshall and Johnston 2010). The most widely used plan is a combination of base salary and financial incentives, such as commission, bonus or sales contests. Sales managers experience challenges in crafting payment plans that use both salary and incentive plans to maximize salespeople's performance as this is very complex, and companies often choose a program based on convenience or cost effectiveness rather than actual benefits to the company.

\section{Compensation initiatives and sales force turnover}

The conceptualization of staff turnover has been well documented for years now. Price (1977) proffers that employee turnover is simply the ratio of the number of employees who have left during the period under consideration divided by the average number of people within the organization. Furthermore, Beach, et.al (2003) defines staff turnover as employee movements from one organization to another which results in vacancies within an organization. The most notable causal factors include among other reasons, retrenchment, dismissals, resignation or expiry of term of contract. Resultantly, high employee turnover lead to high recruitment costs, training costs, depleted skills and low team morale. Abbasi and Hollman (2000) discovered that excessive employee turnover provokes and endangers efforts to achieve desired organizational objectives. Several reasons have been attributed to staff turnover in the insurance industry in developing countries such as Zimbabwe, chief among them are: risky and uncertainty associated with the nature of the job; high pressure job; income and remuneration packages; expectation-achievement gap.

\section{Conceptual model}

CONCEPTUAL MODEL

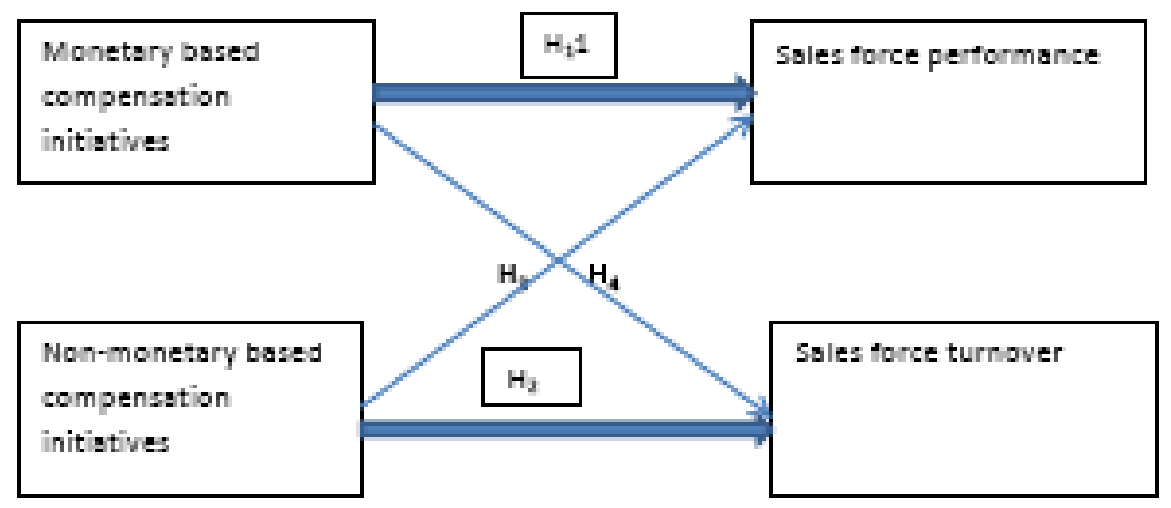

Figure 1: Conceptual model on the impact of compensation initiatives on salesforce performance and turnover

\section{Statement of hypothesis}

The following hypotheses are derived from the foregoing figure 1.

H1: Monetary based compensation strategies positively influences sales performance

H2: Non-monetary compensation packages positively influences sales performance

H3: Monetary based compensation packages positively influence sales force turnover

H4: Non-monetary based compensation packages positively influence sales force turnover

\section{Research methodology}


The aim of this study is to investigate the impact of compensation strategies on sales force performance in the insurance industry. A case study approach was employed to gain an in-depth knowledge of the issue. The case study methodology on selected case companies was chosen to provide an understanding of the dynamics within single real life settings (Yin 1994).

A descriptive research design was employed to evaluate the relationship between sales effort and the company's sales performance. The method was considered ideal for this research study as it allowed for a full comprehension of the impact of sales force compensation initiatives on sales force performance and turnover in the insurance industry. The descriptive research design potrays a clear picture of the key issues under study. Leedy and Ormrod (2005) postulate that the quantitative research techniques are used to answer questions about the relationship among measurable compensation variables with the purpose of explaining, predicting and controlling their effects on sales performance.

A structured questionnaire was used for data collection. The questionnaire comprised of a set of closedend questions relating to the compensation initiatives, incentive schemes and fringe benefits employed by the insurance industry in the Southern Region of Zimbabwe. Study respondents were also asked to respond to questions relating to their involvement in the determination of compensation methods as well as exploring the relationship between compensation methods and salesforce turnover. The data collection instrument was set out into sections to collect data on compensation and motivation, compensation methods currently in use, impact of compensation design on sales force turnover and finally data on a cross sectional demographic patterns was also collected.

A sample size of fifty (50) respondents was used constituting the salesforce from insurance companies in the Southern Region of Zimbabwe. The drop and pick questionnaire administration technique was employed whereby respondents were given ample time to complete the questionnaire which allowed for reliable and better quality responses. The purposive and convenient sampling techniques were employed to select the study participants wherein the researchers' used their knowledge and experience to identify sample units. The SPSS Version 16.0 was used for data analysis and hypothesis testing. Frequency distributions, percentages, measures of central tendencies and dispersions were determined from various tabulations.

\section{Results analysis}

\section{Demographics of respondents}

Table 1: Respondents' demographic data

\begin{tabular}{|c|l|l|}
\hline \multicolumn{1}{|c|}{ Demographic data } & Frequency & Percent (\%) \\
\hline Gender: Male & 34 & 68 \\
Female & 16 & 32 \\
\hline Age: 18-30 years & 22 & 44 \\
31-49 years & 22 & 44 \\
50+ years & 6 & 12 \\
\hline Educational qualifications: Diploma & 38 & 76 \\
Degree & 10 & 20 \\
Other & 2 & 4 \\
\hline
\end{tabular}

The majority of the respondents selected in this study are males within the ages of 18 years to 49 years with most of them holding diploma qualification. $32 \%$ of the respondents were females which suggest maledominance within the insurance industry and this is largely indicative of the nature of the job which requires extensive mobility.

Table 2: Compensation initiatives and sales force performance

\begin{tabular}{|l|l|l|}
\hline & Sales-force performance \\
\hline Monetary based compensation $\left(\mathbf{H}_{\mathbf{1}}\right)$ & Pearson Correlation & -0.22 \\
& Sig. (2-tailed) & 0.125 \\
\hline Non-monetary based compensation $\left(\mathbf{H}_{\mathbf{2}}\right)$ & Pearson Correlation & -0.269 \\
& Sig. (2-tailed) & 0.059 \\
\hline
\end{tabular}

$\mathrm{H}_{1}$ : Monetary based compensation strategies positively influences sales performance

The above results in Table 2 show that the monetary based compensation initiatives and sales force performance are negatively correlated as shown by the Pearson' correlation co-efficient value of -0.22 and significant value of 0.125 which is above the $\mathrm{P}$ value $(\mathrm{p}=0.05)$ value. As such one cannot conclusively deduce that an increase in monetary based compensation will not necessarily result in an increase in sales force performance. In essence, sales force performance can be attributed to several factors other than monetary based compensation schemes 
for instance, issues currently obtaining in the macro-economic environment. Therefore we reject hypothesis statement $\mathrm{H}_{1}$ that monetary based compensation initiatives positively influence sales force performance.

$\mathrm{H}_{2}$ : Non-monetary compensation packages positively influences sales performance

To test the statement of hypothesis $\mathrm{H}_{2}$ bivariate correlations were computed and results presented in Table 2 above. The Pearson correlation co-efficient value of -0.269 indicates that the non-monetary based compensation initiatives are negatively correlated with the sales force performance with the correlation significant value of 0.059 . It is against this background that one can postulate that non-monetary compensation initiatives do not necessarily influence the sales force performance. This concurs with the conclusions made by Johnston and Marshall (2010) that the relationship between performance and rewards is very complex and a firm can use a variety of reward schemes to obtain certain levels of output and outcome. Resultantly, we reject the statement of hypothesis $\mathrm{H}_{2}$ which states that non-monetary compensation packages positively influences sales performance.

Table 3: Monetary and non-monetary compensation initiatives and sales force turnover

\begin{tabular}{|l|l|l|}
\hline & Sales-force turnover \\
\hline Monetary based compensation $\left(\mathbf{H}_{\mathbf{3}}\right)$ & Pearson Correlation & 0.504 \\
& Sig. (2-tailed) & 0.000 \\
\hline Non-monetary based compensation $\left(\mathbf{H}_{\mathbf{4}}\right)$ & Pearson Correlation & -0.031 \\
& Sig. (2-tailed) & 0.832 \\
\hline
\end{tabular}

$\mathrm{H}_{3}$ : Monetary-based compensation packages positively influence sales force turnover

$\mathrm{H}_{3}$ postulates that monetary based compensation packages positively influence sales turnover. The results in Table 3 above show that there is moderate positive relationship between monetary compensation initiatives and sales force turnover as indicated by the Pearson correlation coefficient value of 0.504 and a correlation significant value of 0.000 which denotes a strong relationship $(\mathrm{P}>0.05)$. This entails that in the insurance industry, an organization's commitment to staff welfare for instance adequately compensating and empowering the sales force is critical in motivating staff thereby reducing excessive employee turnover which in-turn enables the attainment of organizational objectives. Rogers and Peccoud (2005) concur that firms that prioritize sales force compensation are more likely to enjoy long-term superior performance.

\section{$\mathrm{H}_{4}$ : Non-monetary based compensation incentives positively influence sales turnover}

The tests with a Pearson value of -0.031 lead us to the conclusion that we should reject $\mathrm{H}_{4}$ which states that non-monetary based compensation incentives positively influence sales force turnover. The negative correlation coefficient value denotes an inverse relationship between non-monetary compensation initiatives and sales force turnover. This is supported by the significant correlation value of 0.832 which is further away from the expected P-value 0.05. This could be due the obtaining macro-economic environment in Zimbabwe which is generally depressed and characterized by high demand for monetary rather than non-monetary remuneration packages. In general, most insurance companies in Zimbabwe are on a recovery path from the economic meltdown of the past decade and hence their focus is more on reducing operational costs thereby shunning the burden that comes with non-monetary compensation packages.

\section{Managerial implications}

There are several issues that the top management in the insurance industry need to note regarding compensation initiatives, sales performance and sales force turnover. Firstly, there is need to balance up monetary based incentives with supportive non-monetary essentials. The behavioral proposition that man is a rational economic being who can be easily motivated by financial rewards do not always hold as there are other variables that can effectively drive sales force performance low or high such as conditions of work, organizational culture, management leadership style and support. Nevertheless, monetary incentives need not be neglected as failure to adequately remunerate workers certainly compromises the attainment of organizational goals. Secondly, sales force turnover just like sales performance is not solely a function or rather dependent on compensation packages, managers need to recognize the impact of other motivational tools depending on the obtaining macro-economic environment. However, it is fundamentally important to highlight that in order for firms to achieve the set goals, there is need for an integrated approach to compensation plans, tactics and management approach in order to have a holistic perspective on the role, effect and significance of the relationship between compensation initiatives and sales performance.

\section{Areas of future research}

The complex nature of implementing compensation plans in the insurance industry requires that management take into cognizance that there is absolute need for continuous research which is longitudinal rather 
cross-sectional in nature so as to gather more credible data which is helpful in solving the dynamic problems associated with the insurance industry. In future prospective researchers may consider testing this proposed hypotheses statements in other fields rather than the insurance industry as this might give different results.

\section{References}

[1]. Abbasi, D, \& Hollman, D 2000, 'Turnover: The Real Bottom Line', Public Personnel Management, 29, 3, p. 333

[2]. Abratt, R, \& Klein, M 1999, 'Sales force compensation and incentive schemes: practices in the South African ..', South African Journal Of Business Management, 30, 3, p. 65

[3]. Albers, S, Mantrala, M, \& Sridhar, S 2010, 'Personal Selling Elasticities: A Meta-Analysis', Journal Of Marketing Research (JMR), 47,5 , pp. 840-853

[4]. Beach, R., D. Brereton and D. Cliff (2003) Workforce Turnover in FIFO Mining Operations in Australia: An Exploratory Study. Brisbane, Centre for Social Responsibility in Mining.

[5]. Blythe, J. 2006 Essentials of Marketing Communications, 3rd Edition; Prentice Hall, New York

[6]. Bonner, S, Hastie, R, Sprinkle, G, \& Young, S 2000, 'A Review of the Effects of Financial Incentives on Performance in Laboratory Tasks: Implications for Management Accounting', Journal Of Management Accounting Research, 12, pp. 19-64

[7]. Bradford, K, \& Weitz, B 2009, 'Salespersons' Management of Conflict in Buyer--Seller Relationships', Journal Of Personal Selling \& Sales Management, 29, 1, pp. 25-42

[8]. Brown, S, Evans, K, Mantrala, M, \& Challagalla, G 2005, 'Adapting motivation, control, and compensation research to a new environment', Journal Of Personal Selling \& Sales Management, 25, 2, pp. 156-167

[9]. Cravens, D.W., IneTam, T.N., LaForge, R.W., and Young, C.E. (1993). Behavior-Based and Outcome-Based Salesforce Control Systems. Journal of Marketing, 57 (October), 47-59

[10]. Cron, W, Dubinsky, A, \& Michaels, R 1988, 'The Influence of Career Stages on Components of Salesperson Motivation', Journal Of Marketing, 52, 1, pp. 78-92

[11]. Financial Gazette (20 August 2012) http://www.financialgazette.co.zw/companies-a-markets/13847-insurers-should-prepare-for-riskbased-capital.html.Acessed 12.03.2013

[12]. Guzzo, RA 1979, 'Types of Rewards, Cognitions, And Work Motivation', Academy Of Management Review, 4, 1, pp. 75-86

[13]. John, G, \& Weitz, B 1989, 'Salesforce Compensation: An Empirical Investigation of Factors Related to Use of Salary Versus Incentive Compensation', Journal Of Marketing Research (JMR), 26, 1, pp. 1-14.

[14]. John, G, \& Weitz, B 1989, 'Salesforce Compensation: An Empirical Investigation of Factors Related to Use of Salary Versus Incentive Compensation', Journal Of Marketing Research (JMR), 26, 1, pp. 1-14

[15]. Johnston, M.W., and Marshall, G.W. 2010 (2008) Relationship Selling.(3rd) ed. McGraw-Hill.

[16]. Kotler and Keller (2012) Marketing Management, Pearson Education,Inc.,Upper Saddle River,New Jersey 07458.

[17]. Leedy and Ormrod (2005) Practical research: Planning and Design,8 Edition, Pearson Education Inc.

[18]. Oliver, R, \& Anderson, E 1995, 'Behavior- and Outcome-Based Sales Control Systems: Evidence and Consequences of Pure-Form and Hybrid Governance', Journal Of Personal Selling \& Sales Management, 15, 4, pp. 1-15

[19]. Piercy and Lane (2009) Strategic Customer Management: Strategizing the sales Organization, Oxford University Press Inc., New York

[20]. Piercy, N, Cravens, D, \& Morgan, N 1999, 'Relationships between Sales Management Control, Territory Design, Salesforce Performance and Sales Organization Effectiveness', British Journal Of Management, 10, 2, pp. 95-111

[21]. Price, J.L (1977). The study of turnover, 1st edition, Iowa state university press, IA pp10-25

[22]. Rogers, P, \& Davis-Peccoud, J 2005, 'Leading From The Front', European Business Forum, 23, pp. 46-50

[23]. Thomas N. Ingram, Raymond W. LaForge, Ramon A. Avila, Charles H. Schwepker, Jr., Michael R. Williams (2007) Professional Selling: A Trust-Based Approach, Fourth Edition, Thomson Corporation.

[24]. Yin (2003) Case study Research. Design Methods, $3{ }^{\text {rd }}$ Edition, Sage Publications 